\title{
Hydrogen Bonding in Phosphonate Cavitands: Investigation of Host-Guest Complexes with Ammonium Salts
}

\author{
Elina Kalenius, ${ }^{\text {a }}$ Raisa Neitola, ${ }^{\text {a }}$ Michele Suman, ${ }^{\mathrm{b}}$ Enrico Dalcanale, ${ }^{\mathrm{b}}$ and \\ Pirjo Vainiotalo ${ }^{a}$ \\ ${ }^{a}$ University of Joensuu, Department of Chemistry, Joensuu, Finland \\ b Università di Parma, Dipartimento di Chimica Organica e Industriale and INSTM, UdR Parma, Parma, Italy
}

\begin{abstract}
The H-bonding in alkylammonium complexes of phosphonate cavitands were studied by mass spectrometric methods and theoretical calculations. The alkylammonium ions included primary, secondary, and tertiary methyl- and ethylammonium ions. Their complexation with mono-, tetra-, and two di-phosphonate cavitands, which differ according to the number and position of $\mathrm{H}$-bond acceptor $\mathrm{P}=\mathrm{O}$ groups, was evaluated by using different competition experiments, energy-resolved CID, gas-phase H/D-exchange, and ligand-exchange reactions, together with ab initio theoretical optimization of the complexes. The phosphonate cavitands with two or more adjacent $\mathrm{P}=\mathrm{O}$ groups were found to be selective towards secondary alkylammonium ions, due to simultaneous formation of two stable hydrogen bonds. In the ion-molecule reactions (both H/D- and ligand-exchange), the formation of two stable hydrogen bonds was observed either to slow down the reaction or to completely prevent it. This was, however, limited to situations where two hydrogen bonds are formed between the $\mathrm{H}$-bond donor sites of the alkyl ammonium ion and the vicinal H-bond acceptor sites of the cavitand. (J Am Soc Mass Spectrom 2010, 21, 440-450) (c) 2010 Published by Elsevier Inc. on behalf of American Society for Mass Spectrometry
\end{abstract}

$\mathrm{T}$ The existence of $\mathrm{H}$-bonds is a source of stability and selectivity observed in various supramolecular systems, and their control is a key issue in the design of new systems, ranging from receptors to molecular machines. Since H-bonding is one of the workhorses of weak interactions, a versatile and efficient methodology capable of assessing the metrics of $\mathrm{H}$-bonding in host/guest complexes is highly desirable. In the past, H-bonding in synthetic supramolecular complexes has mainly been elucidated in the solid-state [1]. More recently, mass spectrometry has become a valuable tool for the characterization of supramolecular assemblies [2]. However, a reliable MS methodology capable of defining number, strength, and mode of $\mathrm{H}$-bonding in supramolecular species is still missing. In this study, we have used a FTICR [3] mass spectrometer as a complete gas-phase laboratory to cover the properties of H-bonded noncovalent complexes of phosphonate cavitands. Ion-molecule reactions have increasingly been used in studies of supramolecular complexes [4], particularly in the gas-phase formation of host-guest complexes $[5,6]$ and enantioselective determinations [7].

The aim of this study was two-fold: (1) to demonstrate the ability of different mass spectrometric exper-

Address reprint requests to Dr. Elina Kalenius, University of Joensuu, Department of Chemistry, P.O. Box 111, FIN-80101 Joensuu, Finland. E-mail: elina.kalenius@uef.fi iments, including competition experiments, CID, and ion-molecule reactions, to determine $\mathrm{H}$-bonding in noncovalent host-guest complexes. This work focuses on ion-molecule reactions, since this type of experiment has been sparingly used in research on $\mathrm{H}$-bonding in supramolecular species. In particular, the H/Dexchange reactions bear real potential for studying the metrics of H-bonding [8]. (2) To clarify the gas-phase properties of complexes formed by phosphonate cavitands, [9] since one of their applications is gas sensing [10]. The earlier reported results have shown that the phosphonate cavitands are capable of selectively forming complexes with alcohols [11-14] and ammonium ions $[7,15,16]$, which has just recently led to application of phosphonate cavitands in supramolecular polymers [17], molecular recognition on silicon surfaces [18], and product protection in amine methylation reactions [19]. Number and positioning of the $\mathrm{P}=\mathrm{O}$ groups at the upper rim and their relative orientation with respect to the cavity are the key host parameters in defining the multiple H-bonding interactions involved in the recognition process [16].

As reported earlier [14], the outward orientation of a $\mathrm{P}=\mathrm{O}$ group with respect to the cavity prevents the complex formation, while the length of the alkyl substituents at the lower rim does not influence complexation. Here, we have concentrated our activity on four cavitands, which differ according to the number and
(C) 2010 Published by Elsevier Inc. on behalf of American Society for Mass Spectrometry. 1044-0305/10/\$32.00

doi:10.1016/j.jasms.2009.11.009
Published online December 11, 2009 Received September 17, 2009 Revised November 24, 2009 Accepted November 24, 2009 
relative position of their inner facing phosphonate bridges (Scheme 1). Complex formation with methyl and ethyl ammonium ions (primary, secondary, and tertiary), stability of the complexes, and H-bonding involved were investigated by means of FTICR mass spectrometry and theoretical calculations.

\section{Experimental}

\section{Chemicals and Samples}

Cavitands (Scheme 1) were prepared by following the published procedures [11, 12, 20]. For the nomenclature used, see reference [9b]. Cavitands were dissolved in toluene. The alkyl ammonium chlorides used are commercially available, and they were dissolved in methanol and then diluted in acetonitrile. Samples were prepared in acetonitrile with a cavitand concentration in the $2.0-4.0 \mu \mathrm{M}$ range and $1: 1$ or in the case of ion-molecule reactions 1:3 cavitand-alkylammonium ion ratios were used.

\section{Instrumentation}

All mass spectrometry experiments were performed with a BioApex 47e Fourier transform ion cyclotron resonance mass spectrometer, equipped with an Infinity cell, a passively shielded 4.7 tesla $160-\mathrm{mm}$ bore superconducting magnet, and an external Apollo electrospray ionization source manufactured by Bruker Daltonics (Billerica MA, USA). The required $1 \times 10^{-9}$ torr vacuum was maintained by rotary vacuum pumps and turbomolecular pumps supplied by Edwards (Edwards High Vacuum International, Crawley, UK). The
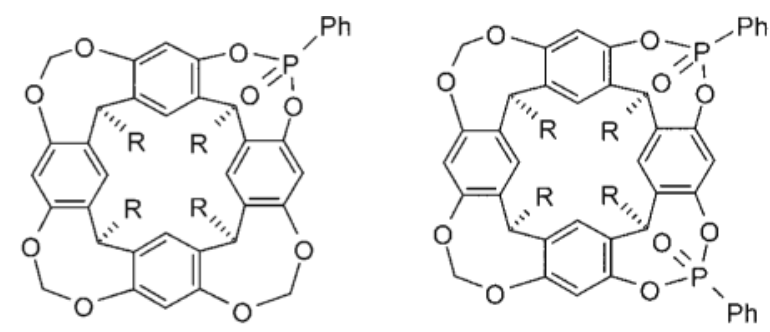

$\operatorname{Mi}\left[\mathrm{C}_{11} \mathrm{H}_{23}, \mathrm{H}, \mathrm{Ph}\right]$

$\mathrm{ABii}\left[\mathrm{C}_{11} \mathrm{H}_{23}, \mathrm{H}, \mathrm{Ph}\right]$

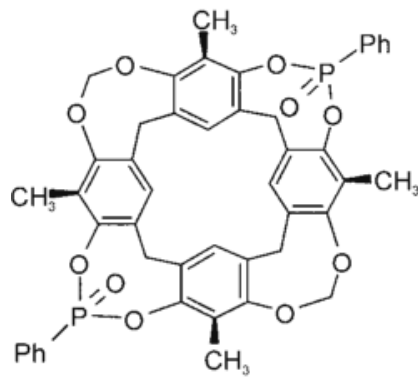

$\mathrm{ACii}\left[\mathrm{H}, \mathrm{CH}_{3}, \mathrm{Ph}\right]$ samples were introduced to a $70^{\circ}$ off-axis sprayer through a syringe infusion pump (Cole-Parmer 74900 series; Cole-Parmer Instrument Company, Vernon Hills, IL, USA) at a flow rate of $90 \mu \mathrm{L} \mathrm{h}^{-1}$. Roomtemperature nitrogen was used as nebulization and counter-current drying gas. Experimental parameters were kept as constant as possible to maintain comparable conditions. Ion-source voltages were mostly adjusted between -3.8 and $-4.0 \mathrm{kV}$ to end plate and between -4.0 and $-4.4 \mathrm{kV}$ to capillary. The capillary exit voltage was adjusted between 100 and $350 \mathrm{~V}$. The Bruker XMASS software, version 6.0.2 was used for the measurement and data handling.

\section{Competition Experiments}

Competition experiments with cavitands were performed with a cavitand / $_{1}$ cavitand 2 1:1 molar ratio. Competition experiments with alkyl ammonium ions were performed with the guests in an equimolar ratio. Each experiment was carried out on five different samples, and each sample was measured five times. The overall variance was calculated from the standard deviation of sampling and the standard deviation of the measurement $\left(\mathrm{s}_{\text {tot }}{ }^{2}=\mathrm{s}_{1}{ }^{2}+\mathrm{s}_{2}{ }^{2}\right)$. Samples or measurements were rejected if the average deviation of a suspect value from the mean was four or more times the average deviation of the retained values [21-23].

\section{Collision Induced Dissociation}

In collision induced dissociation (CID) experiments, collisionally cooled precursor ions were isolated by the CHEF procedure [24]. Isolated ions were translationally activated by an on-resonance radio frequency (rf) pulse, and allowed to collide with pulsed argon background gas. Before activation $3.0 \mathrm{~s}$ delay was used. Each spectrum was background corrected. $\mathrm{E}_{\text {com }}$ values were calculated from experimental parameters using equations presented earlier [25-27]. Peak-to-peak voltage of the excitation rf pulse was measured directly from the output of the rf amplifier. The infinity cell was defined as having a diameter of $6 \mathrm{~cm}$ and a geometrical factor of 0.897. The duration of the excitation pulse was $2 \mathrm{~ms}$.

\section{Ion-Molecule Reactions}

The reagents were introduced to the cell via a variable leak inlet valve and the pressure was allowed to rise to $5 \times 10^{-8}$ torr, where it was kept constant. Ions were isolated and allowed to react with a neutral reagent with delay times from 0.001 up to 300 s. In the ligandexchange reactions, monoisotopic isolations were not pursued, but in $\mathrm{H} / \mathrm{D}$ exchange reactions with $\mathrm{ND}_{3}$, single frequency excitation shots were used to achieve monoisotopic isolations. The spectra consisted of 2, 4, 8, or 16 scans. The number of scans was varied according to the reaction delay needed, while keeping the time of the experiment reasonable. Variation in the number of

Scheme 1. Cavitands studied $\left(\mathrm{R}=\mathrm{C}_{11} \mathrm{H}_{23}\right)$. 
scans did not influence the relative intensities (r.I.) in the resulting spectra. All the spectra were background corrected. The decay of the relative abundance of the reactant ion as a function of time was used to deduce the reaction rate constant $\left(k_{o b s}\right)$. The pressure readings for the neutral reagent were corrected with the measured geometrical correction factors.

\section{Theoretical Calculations}

Geometry optimizations of ethylammonium complexes of cavitands were carried out with density functional BP86 and hybrid density functional B3LYP. The complexation of cavitands with alkylammonium ions $\left(\mathrm{EtNH}_{3}^{+}, \mathrm{Et}_{2} \mathrm{NH}_{2}^{+}\right.$, and $\left.\mathrm{Et}_{3} \mathrm{NH}^{+}\right)$was investigated by using BP86/SVP and B3LYP/SVP. As has been noted [28], the DFT and MP2 theories describe the interactions involved in the complexes in a slightly different way, and MP2 theory would better describe the noncovalent interactions involved in the complexes. Therefore, in addition to the optimization, the single-point energies were calculated for complexes by using the MøllerPlesset (MP) perturbation theory. The MP2 calculations were performed by using the resolution-of-identity (RI) technique, as implemented in TURBOMOLE. Singlepoint MP2 energies were calculated by a triple-valencezeta basis set with polarization functions (TZVP) at the BP86 optimized structures. Geometry optimizations and the energy calculations were performed with the TURBOMOLE 5.9 Program Package [29].

\section{Results and Discussion}

\section{Complex Formation}

All cavitands formed singly charged 1:1 complexes $\left[\mathrm{M}+\mathrm{R}_{\mathrm{n}} \mathrm{NH}_{4-\mathrm{n}}\right]^{+}$with alkylammonium ions. Apart from the alkylammonium complex, adduct ions with adventitious $\mathrm{Na}^{+}$and $\mathrm{NH}_{4}^{+}$were also often observed (Figure 1). Multimers or ions with other charge stages were not observed.

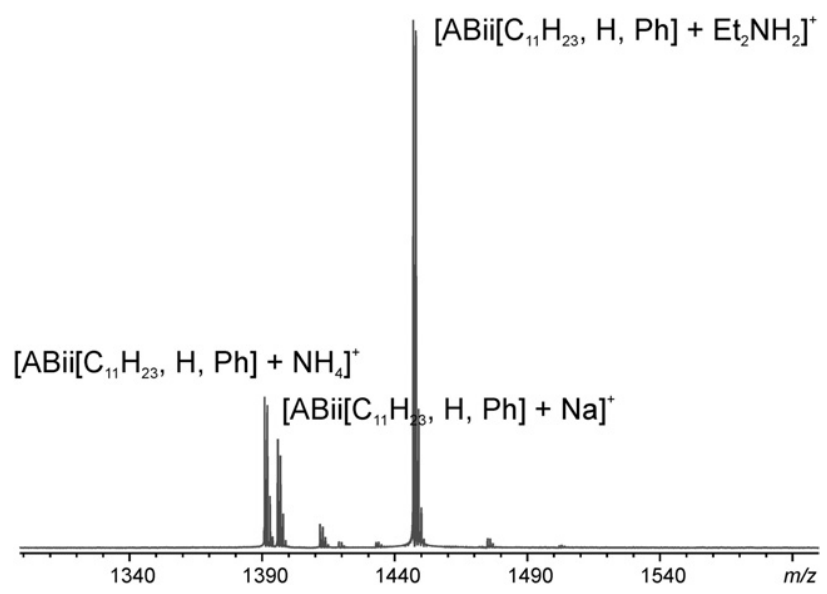

Figure 1. Profile spectrum from a solution containing cavitand $\mathrm{ABii}\left[\mathrm{C}_{11} \mathrm{H}_{23}, \mathrm{H}, \mathrm{Ph}\right]$ and $\mathrm{Et}_{2} \mathrm{NH}-\mathrm{HCl} 1: 1,2 \mu \mathrm{M}$ in ACN.
Table 1. Relative abundances of the complexes from bilateral competition experiments in the presence of a single cavitand

\begin{tabular}{|c|c|c|c|c|c|}
\hline Cavitand & Guest $_{1}$ & Guest $_{2}$ & $\begin{array}{c}\text { r.I. } G_{1} \\
(\%)\end{array}$ & $\begin{array}{c}\text { r.I. } G_{2} \\
(\%)\end{array}$ & $\begin{array}{c}\text { Accuracy } \\
(\%)\end{array}$ \\
\hline $\mathrm{Mi}$ & $\mathrm{MeNH}_{3}{ }^{+}$ & $\mathrm{Me}_{2} \mathrm{NH}_{2}{ }^{+}$ & 47.32 & 52.68 & \pm 11.54 \\
\hline $\mathrm{Mi}$ & $\mathrm{Me}_{2} \mathrm{NH}_{2}{ }^{+}$ & $\mathrm{Me}_{3} \mathrm{NH}^{+}$ & 50.63 & 49.37 & \pm 12.67 \\
\hline Mi & $\mathrm{EtNH}_{3}{ }^{+}$ & $\mathrm{Et}_{2} \mathrm{NH}_{2}{ }^{+}$ & 54.43 & 45.57 & \pm 9.98 \\
\hline $\mathrm{Mi}$ & $\mathrm{Et}_{2} \mathrm{NH}_{2}{ }^{+}$ & $\mathrm{Et}_{3} \mathrm{NH}^{+}$ & 48.10 & 51.90 & \pm 1.63 \\
\hline ACii & $\mathrm{MeNH}_{3}{ }^{+}$ & $\mathrm{Me}_{2} \mathrm{NH}_{2}{ }^{+}$ & 8.15 & 91.85 & \pm 1.01 \\
\hline ACii & $\mathrm{Me}_{2} \mathrm{NH}_{2}{ }^{+}$ & $\mathrm{Me}_{3} \mathrm{NH}^{+}$ & 12.88 & 87.12 & \pm 3.75 \\
\hline $\mathrm{ACii}$ & $\mathrm{EtNH}_{3}{ }^{+}$ & $\mathrm{Et}_{2} \mathrm{NH}_{2}{ }^{+}$ & 24.33 & 75.67 & \pm 4.96 \\
\hline ACii & $\mathrm{Et}_{2} \mathrm{NH}_{2}{ }^{+}$ & $\mathrm{Et}_{3} \mathrm{NH}^{+}$ & 36.46 & 63.54 & \pm 9.32 \\
\hline $\mathrm{ABii}$ & $\mathrm{MeNH}_{3}{ }^{+}$ & $\mathrm{Me}_{2} \mathrm{NH}_{2}{ }^{+}$ & 18.06 & 81.94 & \pm 3.49 \\
\hline $\mathrm{ABii}$ & $\mathrm{Me}_{2} \mathrm{NH}_{2}{ }^{+}$ & $\mathrm{Me}_{3} \mathrm{NH}^{+}$ & 87.12 & 12.88 & \pm 5.28 \\
\hline ABii & $\mathrm{EtNH}_{3}{ }^{+}$ & $\mathrm{Et}_{2} \mathrm{NH}_{2}^{+}$ & 26.16 & 73.84 & \pm 10.77 \\
\hline ABii & $\mathrm{Et}_{2} \mathrm{NH}_{2}{ }^{+}$ & $\mathrm{Et}_{3} \mathrm{NH}^{+}$ & 63.88 & 36.12 & \pm 4.36 \\
\hline $\mathrm{ABii}$ & $\mathrm{Me}_{2} \mathrm{NH}_{2}{ }^{+}$ & $\mathrm{Et}_{2} \mathrm{NH}_{2}{ }^{+}$ & 35.20 & 64.80 & \pm 3.68 \\
\hline Tiiii & $\mathrm{MeNH}_{3}^{+}$ & $\mathrm{Me}_{2} \mathrm{NH}_{2}{ }^{+}$ & 30.10 & 69.90 & \pm 3.79 \\
\hline Tiiii & $\mathrm{Me}_{2} \mathrm{NH}_{2}{ }^{+}$ & $\mathrm{Me}_{3} \mathrm{NH}^{+}$ & 88.64 & 11.36 & \pm 4.51 \\
\hline Tiiii & $\mathrm{EtNH}_{3}{ }^{+}$ & $\mathrm{Et}_{2} \mathrm{NH}_{2}{ }^{+}$ & 22.68 & 77.32 & \pm 5.04 \\
\hline Tiiii & $\mathrm{Et}_{2} \mathrm{NH}_{2}{ }^{+}$ & $\mathrm{Et}_{3} \mathrm{NH}^{+}$ & 86.82 & 13.18 & \pm 4.94 \\
\hline Tiiii & $\mathrm{Me}_{2} \mathrm{NH}_{2}{ }^{+}$ & $\mathrm{Et}_{2} \mathrm{NH}_{2}{ }^{+}$ & 41.00 & 59.00 & \pm 4.85 \\
\hline
\end{tabular}

r.I. = relative intensity .

The competitive complexation experiments were performed between the guests and as well as between the hosts. Cavitand $\mathrm{Mi}\left[\mathrm{C}_{11} \mathrm{H}_{23}, \mathrm{H}, \mathrm{Ph}\right]$ showed no specific affinity for any alkylammonium ion (Table 1 ). However, differences were observed with cavitands $\mathrm{ABii}\left[\mathrm{C}_{11} \mathrm{H}_{23}, \mathrm{H}, \mathrm{Ph}\right], \mathrm{ACii}\left[\mathrm{H}, \mathrm{CH}_{3}, \mathrm{Ph}\right]$, and Tiiii $\left[\mathrm{C}_{11} \mathrm{H}_{23}\right.$, $\mathrm{H}, \mathrm{Ph}]$. The affinity of $\mathrm{ACii}\left[\mathrm{H}, \mathrm{CH}_{3}, \mathrm{Ph}\right]$ towards ammonium ions increased as the substitution degree of the alkyl ammonium ion increased (primary $<$ secondary $<$ tertiary). Yet, cavitands $\mathrm{ABii}\left[\mathrm{C}_{11} \mathrm{H}_{23}, \mathrm{H}, \mathrm{Ph}\right]$ and Tiiii $\left[\mathrm{C}_{11} \mathrm{H}_{23}, \mathrm{H}, \mathrm{Ph}\right]$, which have two adjacent $\mathrm{P}=\mathrm{O}$ groups showed the highest affinity towards secondary alkyl ammoniums and generally the affinity increased in the order primary $\sim$ tertiary $\ll$ secondary (Table 1 ). Moreover, in the case of cavitands $\mathrm{ABii}\left[\mathrm{C}_{11} \mathrm{H}_{23}, \mathrm{H}, \mathrm{Ph}\right]$ and Tiiii $\left[\mathrm{C}_{11} \mathrm{H}_{23}, \mathrm{H}, \mathrm{Ph}\right.$, the longer alkyl chain containing diethylammonium was favored over the dimethylammonium.

The competitive experiments between the cavitands were performed in the presence of a single ethylammonium ion (primary, secondary, or tertiary). The results from these competitions are presented in Figure 2. Regardless of the ethylammonium ion used, the relative affinity of the complexes increased in the order $\mathrm{Mi}\left[\mathrm{C}_{11} \mathrm{H}_{23}, \mathrm{H}, \mathrm{Ph}\right] \sim \mathrm{ACii}\left[\mathrm{H}, \mathrm{CH}_{3}, \mathrm{Ph}\right] \ll \mathrm{ABii}\left[\mathrm{C}_{11} \mathrm{H}_{23}\right.$, $\mathrm{H}, \mathrm{Ph}]<\operatorname{Tiiii}\left[\mathrm{C}_{11} \mathrm{H}_{23}, \mathrm{H}, \mathrm{Ph}\right]$. The most pronounced difference was observed between cavitands $\mathrm{Mi}\left[\mathrm{C}_{11} \mathrm{H}_{23}\right.$, $\mathrm{H}, \mathrm{Ph}]$ and $\mathrm{ABii}\left[\mathrm{C}_{11} \mathrm{H}_{23}, \mathrm{H}, \mathrm{Ph}\right]$. In the case of primary and tertiary ammonium ions, the difference between cavitands $\mathrm{ABii}\left[\mathrm{C}_{11} \mathrm{H}_{23}, \mathrm{H}, \mathrm{Ph}\right]$ and Tiiii $\left[\mathrm{C}_{11} \mathrm{H}_{23}, \mathrm{H}, \mathrm{Ph}\right]$ is substantial, but in the presence of a secondary alkyl ammonium ion, the margin between their relative intensities evens out. In complexation of primary and secondary ethyl ammonium ions, the cavitand $\mathrm{ACii}\left[\mathrm{H}, \mathrm{CH}_{3}, \mathrm{Ph}\right]$ is only slightly favored compared with 
(a)

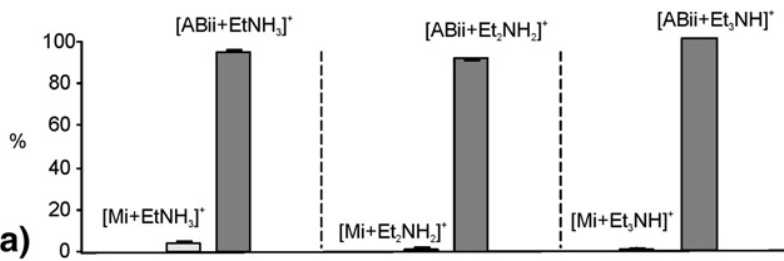

(b)
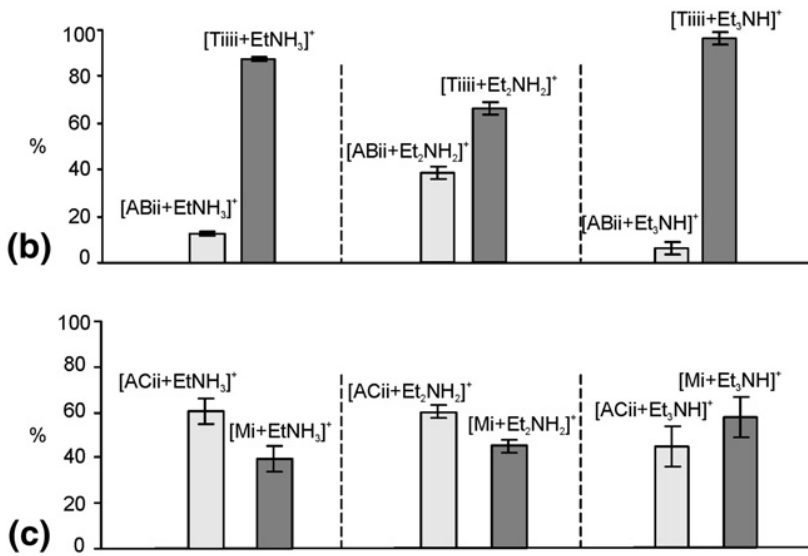

Figure 2. The competitive complexation of cavitands in the presence of (a) $\mathrm{EtNH}_{3}^{+}$, (b) $\mathrm{Et}_{2} \mathrm{NH}_{2}^{+}$, and (c) $\mathrm{Et}_{3} \mathrm{NH}^{+}$.

$\mathrm{Mi}\left[\mathrm{C}_{11} \mathrm{H}_{23}, \mathrm{H}, \mathrm{Ph}\right]$, and within the limits of accuracy there is no evident difference for the complexation of a tertiary ethyl ammonium ion.

These results clearly show that the cavitands with adjacent $\mathrm{P}=\mathrm{O}$ groups (ABii and Tiiii) have the highest affinity towards alkyl ammonium ions. Moreover, results reveal that the cavitands with adjacent $\mathrm{P}=\mathrm{O}$ groups are selective towards secondary alkyl ammonium ions, which are able to operate as two-fold hydrogen bond donors.

\section{Kinetic Stability of the Complexes}

The energy-resolved CID experiments were performed for selected complexes to compare their relative kinetic stability and the mode of dissociation. The CID was performed for all methyl- and ethylammonium complexes of cavitand $\mathrm{ABii}\left[\mathrm{C}_{11} \mathrm{H}_{23}, \mathrm{H}, \mathrm{Ph}\right]$, and ethylammonium complexes of cavitands $\mathrm{Mi}\left[\mathrm{C}_{11} \mathrm{H}_{23}, \mathrm{H}, \mathrm{Ph}\right]$ and Tiiii $\left[\mathrm{C}_{11} \mathrm{H}_{23}, \mathrm{H}, \mathrm{Ph}\right]$.
The proton affinity of the amine corresponding to the ammonium ion used was the paramount factor, which determined the dissociation of the complexes. The complexes formed with ammonium ions whose corresponding amines have relatively low proton affinities dissociated to only $[\mathrm{M}+\mathrm{H}]^{+}$and its fragments or to [M+ $\mathrm{H}]^{+}$and unbound ammonium ion. The observation of a proton transfer provide strong evidence of the hydrogen bonded nature of the complexes and in the CID experiment the complex can be considered a protonbound dimer. Therefore, dissociation of the complexes can be exploited to estimate the proton affinities of the cavitands according to the concept known as Cooks kinetic method [30]. The dissociation pattern of the complexes is presented in Table 2. According to these results, it can be concluded that cavitands Tiiii $\left[\mathrm{C}_{11} \mathrm{H}_{23}\right.$, $\mathrm{H}, \mathrm{Ph}]$ and $\mathrm{ABii}\left[\mathrm{C}_{11} \mathrm{H}_{23}, \mathrm{H}, \mathrm{Ph}\right]$ have higher proton affinities compared with $\mathrm{Mi}\left[\mathrm{C}_{11} \mathrm{H}_{23}, \mathrm{H}, \mathrm{Ph}\right]$ and, more precisely, that the proton affinity of $\mathrm{ABii}\left[\mathrm{C}_{11} \mathrm{H}_{23}, \mathrm{H}, \mathrm{Ph}\right]$ is between 930 and $950 \mathrm{~kJ} \mathrm{~mol}^{-1}$.

The decay of the isolated complex in a CID experiment can be drawn by using either relative intensity (intensity of the isolated ion relative to the sum of ions) or by using normalized intensity (intensity of the isolated ion at certain activation level relative to intensity of the isolated ion at zero activation). In this particular case, it was observed that further dissociation of the $[\mathrm{M}+\mathrm{H}]^{+}$complicated the comparison between the dissociation curves. The $[\mathrm{M}+\mathrm{H}]^{+}$ions dissociated into numerous fragments and the comparison between the maximum (absolute) intensities of the isolated ions and the combined maximum intensities of the fragment ions revealed that a proportion of the fragments remained undetected. Furthermore, at higher activation energies, the collisions of the precursor ions with the surfaces of the cell increase leading to decrease of the absolute intensity of the precursor ion. For these reasons, the relative intensity of the isolated ion was systematically overestimated compared with result produced by normalized intensity. Partly, this phenomenon depends on the proportion of the $[\mathrm{M}+\mathrm{H}]^{+}$formation in the CID process. There were notable differences in the dissociation of the complexes, and generally dissociation of primary ammonium ion complexes results in more production of $[\mathrm{M}+\mathrm{H}]^{+}$, whereas dissociation of ter-

Table 2. Dissociation of the alkyl ammonium complexes of cavitands in CID experiments

\begin{tabular}{|c|c|c|c|c|c|c|c|c|c|c|c|c|c|}
\hline \multirow[b]{2}{*}{ Guest } & \multirow[b]{2}{*}{$\mathrm{PA}^{\mathrm{a}}$} & \multicolumn{4}{|c|}{$\mathrm{Mi}\left[\mathrm{C}_{11} \mathrm{H}_{23}, \mathrm{H}, \mathrm{Ph}\right]$} & \multicolumn{4}{|c|}{$\mathrm{ABii}\left[\mathrm{C}_{11} \mathrm{H}_{23}, \mathrm{H}, \mathrm{Ph}\right]$} & \multicolumn{4}{|c|}{ Tiiii $\left[\mathrm{C}_{11} \mathrm{H}_{23}, \mathrm{H}, \mathrm{Ph}\right]$} \\
\hline & & $\mathrm{M}+\mathrm{H}^{+}$ & Guest $^{+}$ & $\mathrm{E}_{\mathrm{com}}{ }^{50 \% \mathrm{~b}}$ & $\mathrm{E}_{\mathrm{com}}{ }^{0.5 \mathrm{c}}$ & $\mathrm{M}+\mathrm{H}^{+}$ & Guest $^{+}$ & $\mathrm{E}_{\mathrm{com}}{ }^{50 \% \mathrm{~b}}$ & $E_{\text {com }}^{0.5 c}$ & $\mathrm{M}+\mathrm{H}^{+}$ & Guest $^{+}$ & $\mathrm{E}_{\mathrm{com}}{ }^{50 \% \mathrm{~b}}$ & $E_{\text {com }}^{0.5 c}$ \\
\hline $\mathrm{MeNH}_{3}{ }^{+}$ & 899 & $n / d$ & $n / d$ & $n / d$ & $\mathrm{n} / \mathrm{d}$ & Yes & No & 21.96 & 13.91 & $\mathrm{n} / \mathrm{d}$ & $n / d$ & $\mathrm{n} / \mathrm{d}$ & $\mathrm{n} / \mathrm{d}$ \\
\hline $\mathrm{EtNH}_{3}^{+}$ & 912 & Yes & No & 16.50 & 12.83 & Yes & No & 24.82 & 16.97 & Yes & No & 30.25 & 18.37 \\
\hline $\mathrm{Me}_{2} \mathrm{NH}_{2}{ }^{+}$ & 929.5 & $\mathrm{n} / \mathrm{d}$ & $\mathrm{n} / \mathrm{d}$ & $\mathrm{n} / \mathrm{d}$ & $\mathrm{n} / \mathrm{d}$ & Yes & No & 25.84 & 15.41 & $\mathrm{n} / \mathrm{d}$ & $\mathrm{n} / \mathrm{d}$ & $\mathrm{n} / \mathrm{d}$ & $\mathrm{n} / \mathrm{d}$ \\
\hline $\mathrm{Me}_{3} \mathrm{NH}^{+}$ & 948.5 & $n / d$ & $n / d$ & $n / d$ & $n / d$ & Yes & Yes & 18.28 & 15.60 & $n / d$ & $n / d$ & $\mathrm{n} / \mathrm{d}$ & $\mathrm{n} / \mathrm{d}$ \\
\hline $\mathrm{Et}_{2} \mathrm{NH}_{2}^{+}$ & 952.4 & No & Yes & 9.48 & 6.16 & Yes & Yes & 24.56 & 15.98 & Yes & Yes & 35.28 & 16.00 \\
\hline $\mathrm{Et}_{3} \mathrm{NH}^{+}$ & 981.8 & No & Yes & 5.86 & 4.26 & No & Yes & 12.91 & 13.79 & Yes & Yes & 27.53 & 12.46 \\
\hline
\end{tabular}

aProton affinity, $\mathrm{kJ} \mathrm{mol}^{-1}$.

${ }^{b}$ Center-of-mass energy (eV), where r.l. (\%) of the precursor ion is $50 \%$.

${ }^{\mathrm{c}}$ Center-of-mass energy $(\mathrm{eV})$, where n.l. of the precursor ion is 0.5 . 
tiary ammonium ion complexes results in production of tertiary ammonium ion, which leads to smaller overestimation of the relative intensity. Consequently, the comparison of the relative intensities between the complexes does not produce a comparable result. The dissociation curves for dissociation of ethylammonium complexes of cavitand $\mathrm{ABii}\left[\mathrm{C}_{11} \mathrm{H}_{23}, \mathrm{H}, \mathrm{Ph}\right]$ are presented in the Figure 3.

It must be noted that utilization of normalized intensity is not as repeatable as is relative intensity, since there the reference values are obtained by comparison of individual spectra, and all variation in the absolute intensities of the individual spectra decreases the repeatability of the results. Furthermore, it cannot be generally recommended due to increasing surface collisions as with increasing activation energy. However, due to differences in production and dissociation of $[\mathrm{M}+\mathrm{H}]^{+}$ions, in this case the utilization of normalized intensities most likely produce more reliable results compared with relative intensities. Although, both ways to process the data contain unreliability factors the calculated $\mathrm{E}_{\mathrm{com}}{ }^{0.5}$ and $\mathrm{E}_{\mathrm{com}}{ }^{50 \%}$ factors (see Table 2) show increased stability in the case of complexes formed with cavitands Tiiii $\left[\mathrm{C}_{11} \mathrm{H}_{23}, \mathrm{H}, \mathrm{Ph}\right]$ and $\mathrm{ABii}\left[\mathrm{C}_{11} \mathrm{H}_{23}, \mathrm{H}, \mathrm{Ph}\right]$ compared with complexes formed with the cavitand $\mathrm{Mi}\left[\mathrm{C}_{11} \mathrm{H}_{23}, \mathrm{H}\right.$, $\mathrm{Ph}]$, which is inline with the results obtained from competition experiments.

\section{Theoretical Calculations}

The structures of ethyl- and methylammonium complexes were optimized and the single-point energies were calculated for cavitands, with ethyl instead of undecyl chains at the lower rim. The optimized structures of the complexes of $\mathrm{Mi}\left[\mathrm{C}_{2} \mathrm{H}_{5}, \mathrm{H}, \mathrm{Ph}\right], \mathrm{ABii}\left[\mathrm{C}_{2} \mathrm{H}_{5}\right.$, $\mathrm{H}, \mathrm{Ph}]$, and Tiiii $\left[\mathrm{C}_{2} \mathrm{H}_{5}, \mathrm{H}, \mathrm{Ph}\right]$ with ethylammonium ions are presented in Figure 4, and interaction energies for all complexes in Table 3.

In the complexes of $\mathrm{Mi}\left[\mathrm{C}_{2} \mathrm{H}_{5}, \mathrm{H}, \mathrm{Ph}\right]$ with ethyl- or methylammonium ions, there is one hydrogen bond between the $\mathrm{P}=\mathrm{O}$ group of the cavitand and one $\mathrm{NH}$ hydrogen of the ammonium ion at a length of 1.5-1.6. The comparison of the methyl- and ethylammonium complexes reveals that due to steric reasons the meth-

(a)
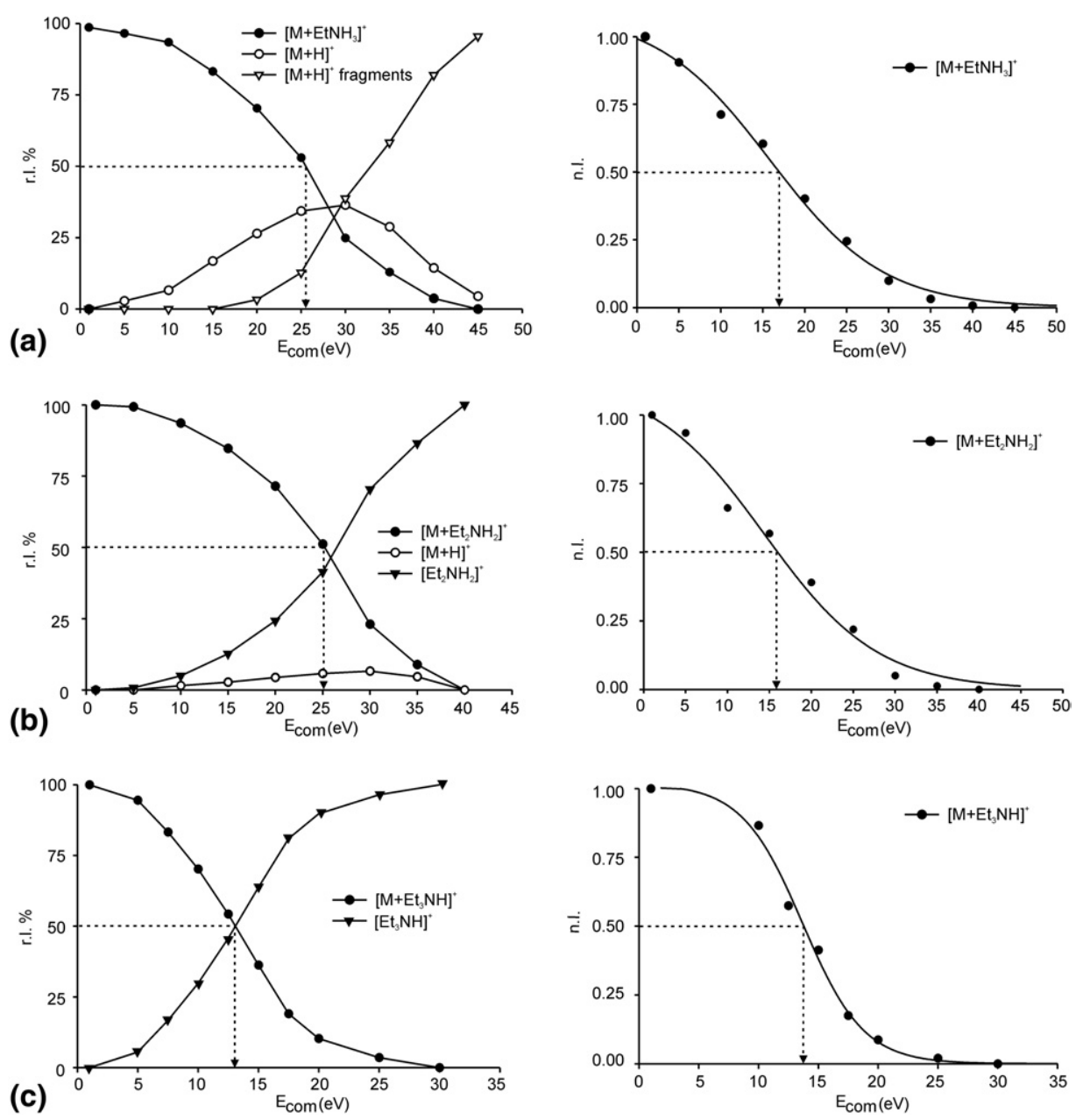

Figure 3. Dissociation curves for (a) $\mathrm{EtNH}_{3}^{+}$, (b) $\mathrm{Et}_{2} \mathrm{NH}_{2}^{+}$, and (c) $\mathrm{Et}_{3} \mathrm{NH}^{+}$complexes of $\mathrm{ABii} \mathrm{C}_{11} \mathrm{H}_{23}$, $\mathrm{H}, \mathrm{Ph}$ ]. For comparison the decay of the abundance for the isolated complex ions is presented as relative (left) and normalized (right) intensities. 

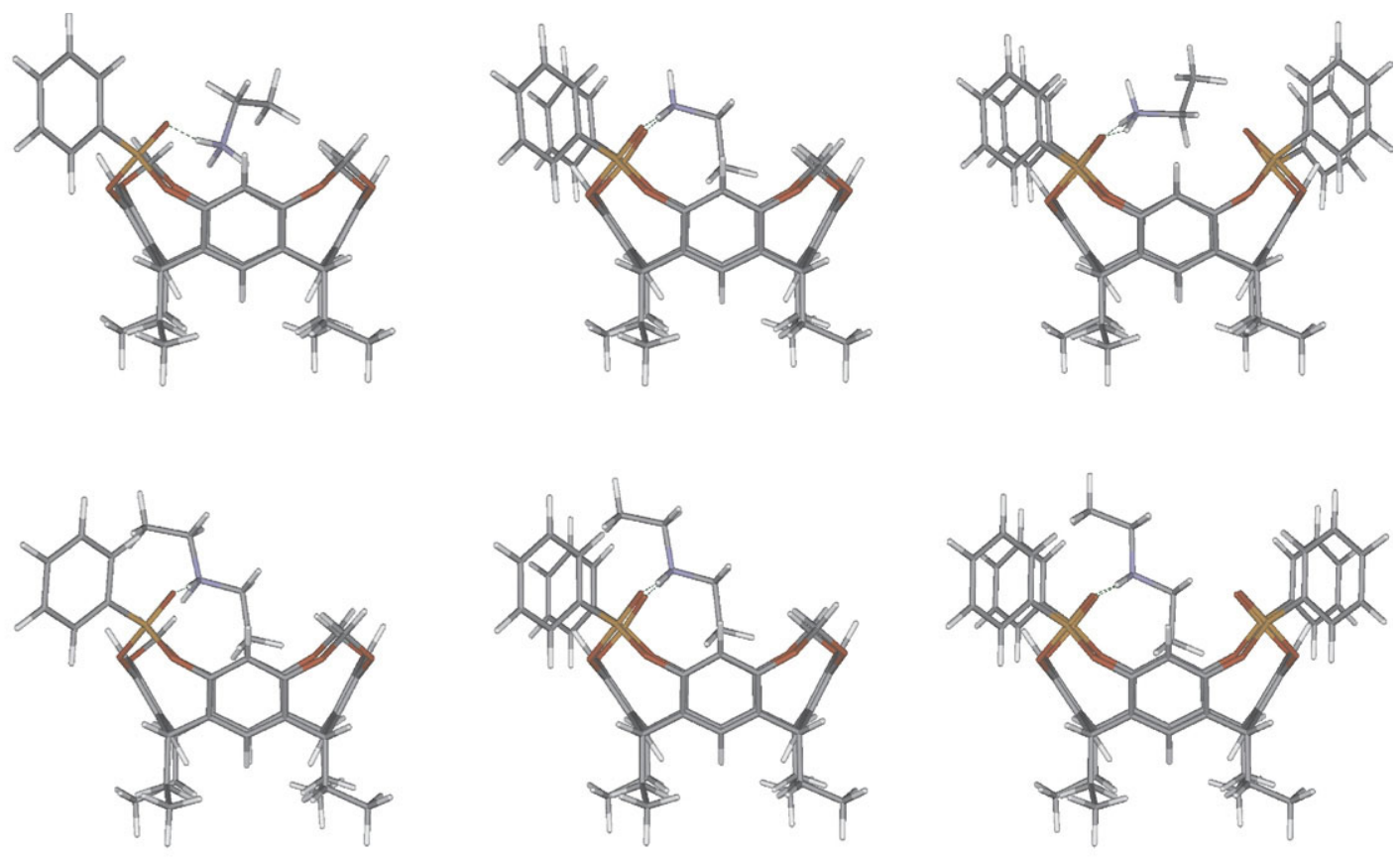

(a)
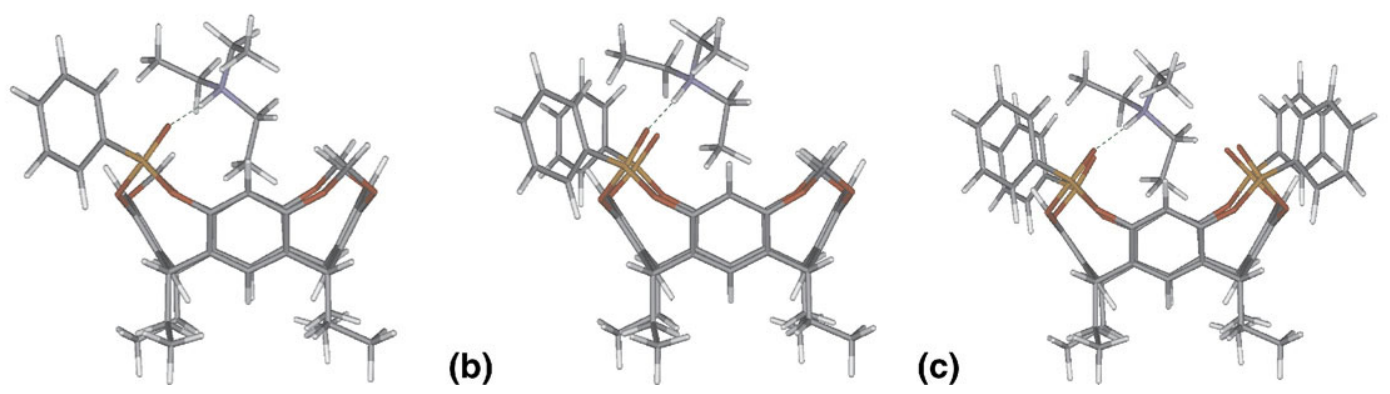

Figure 4. Lowest energy structures for primary (up), secondary (middle), and tertiary (below) ethylammonium ions: (a) $\mathrm{Mi}\left[\mathrm{C}_{2} \mathrm{H}_{5}, \mathrm{H}, \mathrm{Ph}\right]$, (b) $\mathrm{ABii}\left[\mathrm{C}_{2} \mathrm{H}_{5}, \mathrm{H}, \mathrm{Ph}\right]$, and (c) Tiiii $\left[\mathrm{C}_{2} \mathrm{H}_{5}, \mathrm{H}, \mathrm{Ph}\right]$.

ylammonium ions dive deeper into the cavity of $\mathrm{Mi}\left[\mathrm{C}_{2} \mathrm{H}_{5}, \mathrm{H}, \mathrm{Ph}\right]$. The structures of the $\mathrm{ABii}\left[\mathrm{C}_{2} \mathrm{H}_{5}, \mathrm{H}\right.$, $\mathrm{Ph}]$, and Tiiii[ $\left.\mathrm{C}_{2} \mathrm{H}_{5}, \mathrm{H}, \mathrm{Ph}\right]$ complexes are rather similar. Both of them form two hydrogen bonds with primary and secondary ammonium ions, and just one with tertiary ammonium ions. Two structures with closely similar interaction energies were found for primary ammonium complexes of $\left.\mathrm{ABii}_{2} \mathrm{C}_{2} \mathrm{H}_{5}, \mathrm{H}, \mathrm{Ph}\right]$ and Tiiii $\left[\mathrm{C}_{2} \mathrm{H}_{5}, \mathrm{H}, \mathrm{Ph}\right]$. In these structures, the alkyl chain of the ammonium either dives into the cavity or points upwards (see ESI material and Figure 4). Supplementary data can be found in the electronic version of this article. In the Tiiii $\left[\mathrm{C}_{2} \mathrm{H}_{5}, \mathrm{H}, \mathrm{Ph}\right]$ complex with upwards pointed $\mathrm{EtNH}_{3}$, the calculation shows a structure where three hydrogen bonds are formed (see ESI material). The formation of this structure, however, requires significant distortion of the cavitand, although the interaction energy (Table 3) is relatively high. In the solid-state, a triple H-bond host-guest interaction has never been observed with primary ammonium ions [20].

The most significant differences between methyland ethylammonium complexes were found for cavi- tand $\mathrm{ACii}\left[\mathrm{H}, \mathrm{CH}_{3}, \mathrm{Ph}\right]$ (Figure 5). For the complex of $\mathrm{ACii}\left[\mathrm{H}, \mathrm{CH}_{3}, \mathrm{Ph}\right]$ formed with $\mathrm{MeNH}_{3}^{+}$, again two energetically similar structures with alkyl chain diving in or pointing out of the cavity were found. In both structures, there are two hydrogen bonds between the $\mathrm{P}=\mathrm{O}$ groups of the cavitand and $\mathrm{NH}$ protons of the ammonium ions at a length of $1.7 \AA$. It is notable that two hydrogen bonds are formed only if the cavitand is flattened, so that the distance between opposing $\mathrm{P}=\mathrm{O}$ groups becomes shorter. It is also noteworthy that when $\mathrm{CH}_{3}$ of the methylammonium ion is into the cavity, the alkylammonium ion dives deeper into the cavity with respect to any other optimized phosphonate cavitand complexes. According to the interaction energies, the structure in which $\mathrm{CH}_{3}$ dives into the cavity is the most stable one. In the complex of $\mathrm{ACii}\left[\mathrm{H}, \mathrm{CH}_{3}, \mathrm{Ph}\right]$ with $\mathrm{Me}_{2} \mathrm{NH}_{2}^{+}$ion, two hydrogen bonds are also formed (1.9 $\AA$ and $1.8 \AA$ ), while in the complex with $\mathrm{Me}_{3} \mathrm{NH}^{+}$, one $\mathrm{P}=\mathrm{O}$ directed $\mathrm{H}$-bond is formed. In the complex of $\mathrm{ACii}\left[\mathrm{H}, \mathrm{CH}_{3}, \mathrm{Ph}\right]$ with $\mathrm{EtNH}_{3}^{+}$, again two geometries with ethyl pointing either in or out of the cavity were found (see ESI material). However, in this case the 
Table 3. Total energies, interaction energies, and the lengths of hydrogen bonds for the complexes formed between cavitands $\mathrm{Mi}\left[\mathrm{C}_{2} \mathrm{H}_{5}, \mathrm{H}, \mathrm{Ph}\right], \mathrm{ABii}\left[\mathrm{C}_{2} \mathrm{H}_{5}, \mathrm{H}, \mathrm{Ph}\right]$, Tiiii $\left[\mathrm{C}_{2} \mathrm{H}_{5}, \mathrm{H}, \mathrm{Ph}\right]$, and $\mathrm{ACii}\left[\mathrm{C}_{2} \mathrm{H}_{5}, \mathrm{H}, \mathrm{Ph}\right]$, and the alkylammonium ions obtained with a MP2/TZVP level of theory (up and down refer to structures where an alkyl chain of ammonium ions points either up or down from the cavity, see ESI material)

\begin{tabular}{lccc}
\hline \multicolumn{1}{c}{$\mathrm{Complex}$} & Energy $^{\mathrm{a}}$ & $\Delta \mathrm{E}^{\mathrm{b}}$ & $\mathrm{H}$ bond \\
\hline \hline $\mathrm{Mi}+\mathrm{MeNH}_{3}{ }^{+}$ & -2848.5969 & -223 & 1.6 \\
$\mathrm{Mi}+\mathrm{Me}_{2} \mathrm{NH}_{2}{ }^{+}$ & -2887.7873 & -203 & 1.5 \\
$\mathrm{Mi}+\mathrm{Me}_{3} \mathrm{NH}^{+}$ & -2926.9744 & -172 & 1.5 \\
$\mathrm{Mi}+\mathrm{EtNH}_{3}{ }^{+}$(up) & -2887.7853 & -184 & 1.5 \\
$\mathrm{Mi}+\mathrm{EtNH}_{3}{ }^{+}$(down) & -2887.7825 & -177 & 1.5 \\
$\mathrm{Mi}+\mathrm{Et}_{2} \mathrm{NH}_{2}{ }^{+}$ & -2966.1869 & -187 & 1.5 \\
$\mathrm{Mi}+\mathrm{Et}_{3} \mathrm{NH}^{+}$ & -3044.5764 & -168 & 1.6 \\
$\mathrm{ABii}+\mathrm{MeNH}_{3}{ }^{+}$(up) & -3456.4585 & -263 & $2 \times 1.6$ \\
$\mathrm{ABii}+\mathrm{MeNH}_{3}{ }^{+}$(down) & -3456.4651 & -280 & $2 \times 1.6$ \\
$\mathrm{ABii}+\mathrm{Me}_{2} \mathrm{NH}_{2}{ }^{+}$ & -3495.6601 & -273 & $2 \times 1.6$ \\
$\mathrm{ABii}+\mathrm{Me}_{3} \mathrm{NH}^{+}$ & -3534.8323 & -207 & 1.6 \\
$\mathrm{ABii}+\mathrm{EtNH}_{3}{ }^{+}$(up) & -3495.6617 & -263 & $2 \times 1.6$ \\
$\mathrm{ABii}+\mathrm{EtNH}_{3}{ }^{+}$(down) & -3495.6678 & -279 & $2 \times 1.6$ \\
$\mathrm{ABii}+\mathrm{Et}_{2} \mathrm{NH}_{2}{ }^{+}$ & -3574.0657 & -273 & $2 \times 1.7$ \\
$\mathrm{ABii}+\mathrm{Et}_{3} \mathrm{NH}^{+}$ & -3652.4357 & -202 & 1.6 \\
$\mathrm{Tiiii}+\mathrm{MeNH}_{3}{ }^{+}$(up) & -4672.1794 & -350 & $2 \times 1.7$ \\
$\mathrm{Tiiii}+\mathrm{MeNH}_{3}{ }^{+}$(down) & -4672.1805 & -353 & $2 \times 1.7$ \\
$\mathrm{Tiiii}+\mathrm{Me}_{2} \mathrm{NH}_{2}{ }^{+}$ & -4711.3849 & -370 & $2 \times 1.7$ \\
$\mathrm{Tiiii}+\mathrm{Me}_{3} \mathrm{NH}^{+}$ & -4750.5568 & -298 & 1.7 \\
$\mathrm{Tiiii}+\mathrm{EtNH}_{3}{ }^{+}$(up) & -4711.3836 & -352 & $2 \times 1.8,1.7$ \\
$\mathrm{Tiiii}+\mathrm{EtNH}_{3}{ }^{+}$(down) & -4711.3724 & -323 & $2 \times 1.7$ \\
$\mathrm{Tiiii}+\mathrm{Et}_{2} \mathrm{NH}_{2}{ }^{+}$ & -4789.7853 & -355 & $2 \times 1.7$ \\
$\mathrm{Tiiii}+\mathrm{Et}_{3} \mathrm{NH}^{+}$ & -4868.1626 & -305 & 1.7 \\
$\mathrm{ACii}+\mathrm{MeNH}_{3}{ }^{+}$(up) & -3299.6788 & -253 & $2 \times 1.7$ \\
$\mathrm{ACii}+\mathrm{MeNH}_{3}{ }^{+}$(down) & -3299.6867 & -274 & $2 \times 1.7$ \\
$\mathrm{ACii}+\mathrm{Me}_{2} \mathrm{NH}_{2}{ }^{+}$ & -3338.8801 & -262 & $1.8,1.9$ \\
$\mathrm{ACii}+\mathrm{Me}_{3} \mathrm{NH}^{+}$ & -3378.0718 & -243 & 1.6 \\
$\mathrm{ACii}+\mathrm{EtNH}_{3}{ }^{+}$(up) & -3338.8819 & -253 & $2 \times 1.7$ \\
$\mathrm{ACii}+\mathrm{EtNH}_{3}{ }^{+}$(down) & -3338.8742 & -233 & 1.5 \\
$\mathrm{ACii}+\mathrm{Et}_{2} \mathrm{NH}_{2}{ }^{+}$ & -3417.2696 & -219 & 1.6 \\
$\mathrm{ACii}+\mathrm{Et}_{3} \mathrm{NH}^{+}$ & -3495.6698 & -229 & 1.7 \\
\hline & & &
\end{tabular}

aTotal energies (a.u.).

bInteraction energies ( $\left.\mathrm{kJ} \mathrm{mol}{ }^{-1}\right)$.

'The length of hydrogen bonds $(\AA)$

geometry in which the ethyl group of the ammonium ion dives inside the cavity is not the most stable one, because it can form only one hydrogen bond, whereas two hydrogen bonds are possible in the geometry in which the ethyl points outwards from the cavity. The ethyl group cannot dive as deep inside the cavity as the methyl, so a similar orientation is not possible. Respectively, the bulkiness of the ethyl group prevents the formation of two hydrogen bonds between ACii[H, $\left.\mathrm{CH}_{3}, \mathrm{Ph}\right]$ and $\mathrm{Et}_{2} \mathrm{NH}_{2}^{+}$ion. Since $\mathrm{ACii}\left[\mathrm{H}, \mathrm{CH}_{3}, \mathrm{Ph}\right]$ showed big differences between the complexation of methyl- and ethylammonium ions, the corresponding complexes of $\mathrm{ABii}\left[\mathrm{H}, \mathrm{CH}_{3}, \mathrm{Ph}\right]$ were also optimized. The theoretical modeling was, however, comparable with those of $\mathrm{ABii}\left[\mathrm{C}_{2} \mathrm{H}_{5}, \mathrm{H}, \mathrm{Ph}\right]$, suggesting that the experimental differences observed in complexes of ACii $\left[\mathrm{H}, \mathrm{CH}_{3}, \mathrm{Ph}\right]$ are related to the relative positioning of the $\mathrm{P}=\mathrm{O}$ groups rather than to the presence of the apical methyl groups.
The formation of an additional $\mathrm{H}$-bond in most of the complexes of $\mathrm{ABii}\left[\mathrm{C}_{2} \mathrm{H}_{5}, \mathrm{H}, \mathrm{Ph}\right]$ and Tiiii $\left[\mathrm{C}_{2} \mathrm{H}_{5}, \mathrm{H}, \mathrm{Ph}\right]$ clearly increases the interactions energies $\left(>50 \mathrm{~kJ} \mathrm{~mol}^{-1}\right)$. However, similar increase in energy is not observed for the complexes in which formation of additional $\mathrm{H}$ bonds occurs at the cost of cavitand distortion (e.g., Tiiii + $\mathrm{EtNH}_{3}$ (down), ACii $+\mathrm{MeNH}_{3}, \mathrm{ACii}+\mathrm{Me}_{2} \mathrm{NH}_{2}$ ). In distorted structures, the $\mathrm{H}$-bonds are often slightly longer compared with rest of the structures, and the cavitand has increased energy resulting from molecular strain. Between the methyl- and ethylammonium complexes of $\mathrm{ABii}\left[\mathrm{C}_{2} \mathrm{H}_{5}, \mathrm{H}, \mathrm{Ph}\right]$ and $\mathrm{Tiiii}\left[\mathrm{C}_{2} \mathrm{H}_{5}, \mathrm{H}, \mathrm{Ph}\right]$ significant energy differences are not observed. Yet, among the complexes of $\mathrm{Mi}\left[\mathrm{C}_{2} \mathrm{H}_{5}, \mathrm{H}, \mathrm{Ph}\right]$ and $\mathrm{ACii}[\mathrm{H}$, $\left.\mathrm{CH}_{3}, \mathrm{Ph}\right]$, slightly higher interaction energies were observed for methylammonium complexes. Furthermore, the comparison between the cavitands reveals that generally the interaction energies increase in the order $\mathrm{Mi}\left[\mathrm{C}_{2} \mathrm{H}_{5}, \mathrm{H}, \mathrm{Ph}\right]\left(\sim 170-220 \mathrm{~kJ} \mathrm{~mol}^{-1}\right) \ll \mathrm{ACii}[\mathrm{H}$, $\left.\mathrm{CH}_{3}, \mathrm{Ph}\right]\left(\sim 220-270 \mathrm{~kJ} \mathrm{~mol}{ }^{-1}\right)<\mathrm{ABii}\left[\mathrm{C}_{2} \mathrm{H}_{5}, \mathrm{H}, \mathrm{Ph}\right]$ $\left(\sim 200-280 \mathrm{~kJ} \mathrm{~mol}^{-1}\right) \ll \operatorname{Tiiii}\left[\mathrm{C}_{2} \mathrm{H}_{5}, \mathrm{H}, \mathrm{Ph}\right](\sim 300-350 \mathrm{~kJ}$ $\left.\mathrm{mol}^{-1}\right)$.

\section{Gas-Phase Ion-Molecule Reactions}

We have previously reported results concerning the $\mathrm{H} / \mathrm{D}$-exchange and ligand-exchange with propylamine for the ethyl ammonium complexes of cavitands [16]. According our earlier observations, it seemed that cavitands are able to utilize only two adjacent phosphonate groups simultaneously for interaction with alkyl ammonium ions. In the case of primary and secondary ethyl ammonium ions kinetically stable hydrogen bonding interaction pattern is formed only if the available hydrogen bond acceptor sites of the cavitand equals the hydrogen bond donor sites of the ammonium ion in number and simultaneous availability. However, proton affinity difference between the complex under study and H/D-exchange reagent usually has a great impact on the reaction itself. Therefore, it was necessary for us to complete the earlier presented results and to also perform the reactions with methylammonium complexes. The $\mathrm{H} / \mathrm{D}$-exchange reactions were performed by using $\mathrm{ND}_{3}$ as reagent and ligandexchange by using $\operatorname{PrNH}_{2}, \operatorname{Pr}_{2} \mathrm{NH}$, and $i-\mathrm{PrNH}_{2}$.

\section{$H / D$-Exchange}

As in the case of primary ethylammonium complexes, the complexes with primary methylammonium ions also exchanged all NH hydrogens to deuterium (Table $4)$ and the reaction rate for the first exchange $\left(\mathrm{k}_{1}\right)$ was clearly lower for complexes of $\mathrm{ABii}\left[\mathrm{C}_{11} \mathrm{H}_{23}, \mathrm{H}, \mathrm{Ph}\right]$ and Tiiii $\left[\mathrm{C}_{11} \mathrm{H}_{23}, \mathrm{H}, \mathrm{Ph}\right]$. It must be noted that in terms of reaction rates, the repeatability of the gas-phase ionmolecule reactions is rarely excellent. The reading of reagent pressure is based on the pressure reading in the ICR cell and daily variations in the absolute pressure as well as the variation in the sensitivity of the gauge for 
(a)
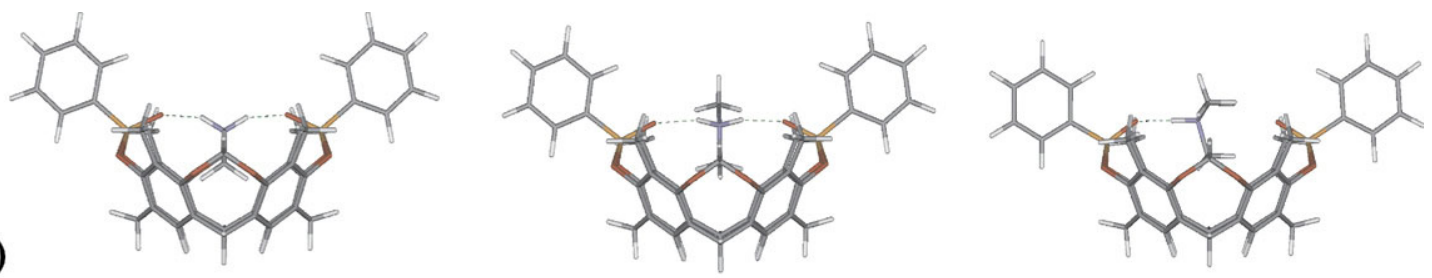

(b)
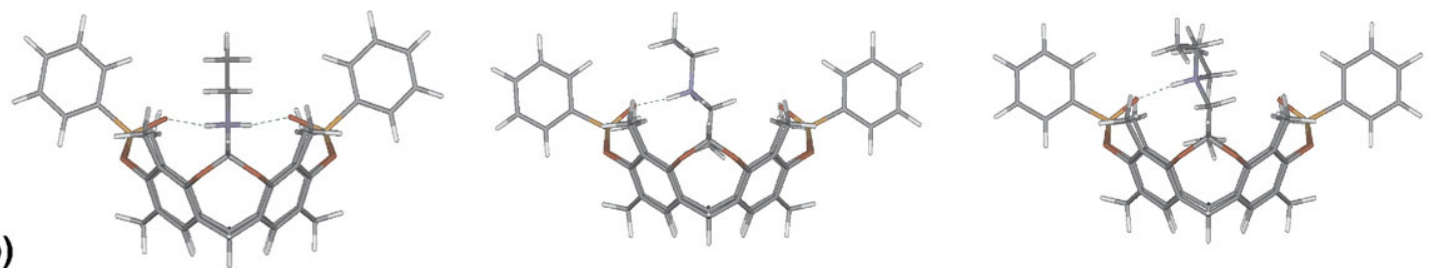

Figure 5. Lowest energy structures for primary, secondary and tertiary (a) methyl, and (b) ethyl ammonium complexes of ACii $\left[\mathrm{H}, \mathrm{CH}_{3}, \mathrm{Ph}\right]$.

different reagents cause variation in the observed reaction rates.

In the case of secondary alkyl ammonium ions, the cavitands with adjacent $\mathrm{P}=\mathrm{O}$ groups (ABii and Tiiii) do not exchange any hydrogen, whereas the complexes of cavitands $\mathrm{Mi}\left[\mathrm{C}_{11} \mathrm{H}_{23}, \mathrm{H}, \mathrm{Ph}\right]$ and $\mathrm{ACii}\left[\mathrm{H}, \mathrm{CH}_{3}, \mathrm{Ph}\right]$ exchange both hydrogens with a reasonable reaction rate. This is in line with the results obtained earlier with the diethylammonium complexes, but in the case of $\mathrm{ACii}\left[\mathrm{H}, \mathrm{CH}_{3}, \mathrm{Ph}\right]$, there is a clear inconsistency compared with theoretical calculations, which showed formation of two H-bonds between the distorted cavitand ACii $\left[\mathrm{H}, \mathrm{CH}_{3}, \mathrm{Ph}\right]$ and $\mathrm{Me}_{2} \mathrm{NH}_{2}^{+}$. Considering the lack of selectivity of ACii $\left[\mathrm{H}, \mathrm{CH}_{3}, \mathrm{Ph}\right]$ towards secondary alkyl ammoniums in competition experiments and the observed difference in reaction behavior between the ABii and ACii cavitands, it is reasonable to assume that under experimental conditions, the distortion of the ACii cavitand and the formation of two hydrogen bonds does not take place.

We previously reported [16] that the triethyl ammonium complexes were not reacting, and the reason was attributed to a relatively high proton affinity of the triethyl amine. According to results obtained with methylammonium complexes, this conclusion seems reasonable, since $\mathrm{Me}_{3} \mathrm{NH}^{+}$complexes of cavitands $\mathrm{Mi}\left[\mathrm{C}_{11} \mathrm{H}_{23}, \mathrm{H}, \mathrm{Ph}\right], \mathrm{ABii}\left[\mathrm{C}_{11} \mathrm{H}_{23}, \mathrm{H}, \mathrm{Ph}\right]$, and Tiiii $\left[\mathrm{C}_{11} \mathrm{H}_{23}, \mathrm{H}, \mathrm{Ph}\right]$ exchanged the $\mathrm{NH}$ hydrogen to deuterium, although the reaction rates for $\mathrm{Mi}\left[\mathrm{C}_{11} \mathrm{H}_{23}\right.$,
$\mathrm{H}, \mathrm{Ph}]$ and Tiiii $\left[\mathrm{C}_{11} \mathrm{H}_{23}, \mathrm{H}, \mathrm{Ph}\right]$ complexes were relatively low. In ACii $\left[\mathrm{C}_{11} \mathrm{H}_{23}, \mathrm{H}, \mathrm{Ph}\right]$, the absence of $\mathrm{H} / \mathrm{D}$ exchange is likely due to steric hindrance among the apical methyl groups of the cavitand and the three methyl groups of the $\mathrm{Me}_{3} \mathrm{NH}^{+}$. Therefore, besides the hydrogen bonding and proton affinity difference, the steric hindrance in the complexes also has to be considered when conclusions are made on the basis of $\mathrm{H} / \mathrm{D}$-exchange.

\section{Ligand-Exchange Reactions}

As in the H/D-exchange, in ligand-exchange reactions all complexes formed with primary alkyl ammonium ions exchanged relatively fast with propylamine (n-, di-, or iso-). Regardless of the cavitand, in the complexes formed with primary ammonium ions there is at least one unbound hydrogen, which is accessible for reaction. However, in the reactions of the complexes formed with secondary ammonium ions the reaction rate is very slow or reaction does not occur at all. Particular attention should be paid to the secondary ammonium complexes of $\mathrm{ACii}\left[\mathrm{H}, \mathrm{CH}_{3}, \mathrm{Ph}\right]$. The effect of steric hindrance on reaction rates is observed as the bulkiness of the reagent increases: this is more pronounced for the $\mathrm{Me}_{2} \mathrm{NH}_{2}^{+}$complex than for the $\mathrm{Et}_{2} \mathrm{NH}_{2}^{+}$complex. Otherwise, a clear effect of proton affinities is observed when rates of secondary methylammonium complexes

Table 4. Observed $\mathrm{H} / \mathrm{D}$-exchange reaction rate constants and the number of $\mathrm{H} / \mathrm{D}$ exchanges

\begin{tabular}{|c|c|c|c|c|c|c|c|c|c|}
\hline & \multicolumn{3}{|c|}{$\mathrm{MeNH}_{3}{ }^{+}$} & \multicolumn{3}{|c|}{$\mathrm{Me}_{2} \mathrm{NH}_{2}{ }^{+}$} & \multicolumn{3}{|c|}{$\mathrm{Me}_{3} \mathrm{NH}^{+}$} \\
\hline & $\mathrm{H} / \mathrm{D}$ & $\mathrm{k}_{1}(\exp )$ & $\mathrm{R}^{2}$ & $\mathrm{H} / \mathrm{D}$ & $\mathrm{k}_{1}(\exp )$ & $\mathrm{R}^{2}$ & $\mathrm{H} / \mathrm{D}$ & $\mathrm{k}_{1}(\exp )$ & $\mathrm{R}^{2}$ \\
\hline $\mathrm{Mi}\left[\mathrm{C}_{11} \mathrm{H}_{23}, \mathrm{H}, \mathrm{Ph}\right]$ & 3 & 71.6 & 0.966 & 2 & 6.79 & 0.995 & 1 & 0.48 & 0.983 \\
\hline $\mathrm{ACii}\left[\mathrm{H}, \mathrm{CH}_{3}, \mathrm{Ph}\right]$ & 3 & 136 & 0.986 & 2 & 12.4 & 0.993 & 0 & - & - \\
\hline $\mathrm{ABii}\left[\mathrm{C}_{11} \mathrm{H}_{23}, \mathrm{H}, \mathrm{Ph}\right]$ & 3 & 2.52 & 0.999 & 0 & - & - & 1 & 6.08 & 0.991 \\
\hline $\operatorname{Tiiii}\left[\mathrm{C}_{11} \mathrm{H}_{23}, \mathrm{H}, \mathrm{Ph}\right]$ & 3 & 8.24 & 0.998 & 0 & - & - & 1 & 0.20 & 0.954 \\
\hline
\end{tabular}

$\mathrm{k}_{1}=10^{-12} \mathrm{~cm}^{3} \mathrm{~s}^{-1} \mathrm{~mol}^{-1}$. 
Table 5. Ligand-exchange reactions of methyl ammonium complexes

\begin{tabular}{|c|c|c|c|c|c|c|c|}
\hline \multirow[b]{2}{*}{ Reagent } & \multirow[b]{2}{*}{ Cavitand } & \multicolumn{2}{|c|}{$\mathrm{MeNH}_{3}{ }^{+}$} & \multicolumn{2}{|c|}{$\mathrm{Me}_{2} \mathrm{NH}_{2}{ }^{+}$} & \multicolumn{2}{|c|}{$\mathrm{Me}_{3} \mathrm{NH}^{+}$} \\
\hline & & $\mathrm{k}_{\exp }{ }^{a}$ & $\mathrm{R}^{2 \mathrm{~b}}$ & $\mathrm{k}_{\exp }{ }^{\mathrm{a}}$ & $\mathrm{R}^{2 \mathrm{~b}}$ & $\mathrm{k}_{\exp }{ }^{\mathrm{a}}$ & $\mathrm{R}^{2 \mathrm{~b}}$ \\
\hline $\mathrm{PrNH}_{2}$ & $\mathrm{Mi}\left[\mathrm{C}_{11} \mathrm{H}_{23}, \mathrm{H}, \mathrm{Ph}\right]$ & 355 & 0.995 & 51.8 & 0.997 & \multicolumn{2}{|c|}{$n / d$} \\
\hline $\mathrm{PrNH}_{2}$ & $\mathrm{ACii}\left[\mathrm{H}, \mathrm{CH}_{3}, \mathrm{Ph}\right]$ & 275 & 0.992 & 2.84 & 0.999 & \multicolumn{2}{|c|}{$n / d$} \\
\hline $\mathrm{PrNH}_{2}$ & $\mathrm{ABii}\left[\mathrm{C}_{11} \mathrm{H}_{23}, \mathrm{H}, \mathrm{Ph}\right]$ & 157 & 0.995 & 0.59 & 0.991 & \multicolumn{2}{|c|}{$n / d$} \\
\hline $\mathrm{PrNH}_{2}$ & $\operatorname{Tiiii}\left[\mathrm{C}_{11} \mathrm{H}_{23}, \mathrm{H}, \mathrm{Ph}\right]$ & 202 & 0.993 & 0.38 & 0.953 & \multicolumn{2}{|c|}{$\mathrm{n} / \mathrm{d}$} \\
\hline $\mathrm{Pr}_{2} \mathrm{NH}$ & $\mathrm{Mi}\left[\mathrm{C}_{11} \mathrm{H}_{23}, \mathrm{H}, \mathrm{Ph}\right]$ & 293 & 0.981 & 83.2 & 0.999 & 86.0 & 0.995 \\
\hline $\mathrm{Pr}_{2} \mathrm{NH}$ & $\mathrm{ACii}\left[\mathrm{H}, \mathrm{CH}_{3}, \mathrm{Ph}\right]$ & 99.6 & 0.996 & 1.94 & 0.999 & \multicolumn{2}{|c|}{ No exchange } \\
\hline $\mathrm{Pr}_{2} \mathrm{NH}$ & $\mathrm{ABii}\left[\mathrm{C}_{11} \mathrm{H}_{23}, \mathrm{H}, \mathrm{Ph}\right]$ & 208 & 0.997 & 2.85 & 0.990 & 165 & 0.994 \\
\hline $\mathrm{Pr}_{2} \mathrm{NH}$ & $\operatorname{Tiiii}\left[\mathrm{C}_{11} \mathrm{H}_{23}, \mathrm{H}, \mathrm{Ph}\right]$ & 7.18 & 0.990 & \multicolumn{2}{|c|}{ No exchange } & 0.83 & 0.972 \\
\hline i-PrNH 2 & $\mathrm{Mi}\left[\mathrm{C}_{11} \mathrm{H}_{23}, \mathrm{H}, \mathrm{Ph}\right]$ & 92.4 & 0.998 & 2.59 & 0.995 & \multicolumn{2}{|c|}{$n / d$} \\
\hline $\mathrm{i}-\mathrm{PrNH}_{2}$ & $\mathrm{ACii}\left[\mathrm{H}, \mathrm{CH}_{3}, \mathrm{Ph}\right]$ & 162 & 0.992 & 0.81 & 0.983 & \multicolumn{2}{|c|}{$\mathrm{n} / \mathrm{d}$} \\
\hline $\mathrm{i}-\mathrm{PrNH}{ }_{2}$ & $\mathrm{ABii}\left[\mathrm{C}_{11} \mathrm{H}_{23}, \mathrm{H}, \mathrm{Ph}\right]$ & 197 & 0.994 & 0.95 & 0.986 & \multicolumn{2}{|c|}{$\mathrm{n} / \mathrm{d}$} \\
\hline $\mathrm{i}-\mathrm{PrNH}_{2}$ & $\operatorname{Tiiii}\left[\mathrm{C}_{11} \mathrm{H}_{23}, \mathrm{H}, \mathrm{Ph}\right]$ & 154 & 0.996 & \multicolumn{2}{|c|}{ No exchange } & \multicolumn{2}{|c|}{$\mathrm{n} / \mathrm{d}$} \\
\hline
\end{tabular}

${ }^{a} k_{\exp }=10^{-12} \mathrm{~cm}^{3} \mathrm{~s}^{-1} \mathrm{~mol}^{-1}$

${ }^{\mathrm{b}}$ Correlation of sigmoidal fit.

are compared with the rates of ethylammonium complexes (Tables 5 and 6).

Among the triethylammonium complexes the reaction is only observed in the case of the $A B i i\left[\mathrm{C}_{11} \mathrm{H}_{23}, \mathrm{H}\right.$, $\mathrm{Ph}$ ] cavitand, and also the reaction rate for the corresponding $\mathrm{Me}_{3} \mathrm{NH}^{+}$complex is higher compared with rates for equal complexes formed with other cavitands. In addition, it must also be noted that in the H/Dexchange reactions the reaction rate of the $\mathrm{Me}_{3} \mathrm{NH}^{+}$ complex of cavitand $\mathrm{ABii}\left[\mathrm{C}_{11} \mathrm{H}_{23}, \mathrm{H}, \mathrm{Ph}\right]$ was increased compared with rates of the corresponding complexes formed with the rest of the cavitands. Therefore, it can be assumed that the $\mathrm{Et}_{3} \mathrm{NH}^{+}$complex of cavitand $\mathrm{ABii}\left[\mathrm{C}_{11} \mathrm{H}_{23}, \mathrm{H}, \mathrm{Ph}\right]$ might resemble a pendulum (Figure 6) and the two adjacent $\mathrm{P}=\mathrm{O}$ weakens the single $\mathrm{H}$-bond formed and increases the reaction rate. Similarly, Tiiii $\left[\mathrm{C}_{11} \mathrm{H}_{23}, \mathrm{H}, \mathrm{Ph}\right]$ forms rather stable complexes with secondary ammonium ions. The hoop arrangement of the four $\mathrm{P}=\mathrm{O}$ groups enables the guest to rapidly change its $\mathrm{H}$-bonding pattern with the host over time, although, on average, the cavitand does not form more than two H-bonds.

\section{Conclusions}

Phosphonate cavitands with two adjacent $\mathrm{P}=\mathrm{O}$ groups were found to complex secondary alkyl ammonium ions in the gas phase with high selectivity. These results nicely complement and support those reported in solution [31] and in the solid-state [18] for Tiiii cavitands. According to the results presented here, this selectivity arises from simultaneous formation of two stable hydrogen bonds. This was clearly demonstrated in competition experiments. According to the CID results, the increased kinetic stability of the complexes formed with di- and tetra- $\mathrm{P}=\mathrm{O}$ cavitands was also evident. In the ion-molecule reactions (both H/D- and ligandexchange), the formation of two stable hydrogen bonds either slowed down the reaction or completely suppressed it. This selectivity is limited to the case in which two hydrogen bonds are formed. Otherwise, the $\mathrm{H}$ bonding pattern resembles a pendulum (e.g., $[\mathrm{ABii}+$ $\left.\mathrm{R}_{3} \mathrm{NH}\right]^{+}$, [Mi $\left.+\mathrm{R}_{2} \mathrm{NH}_{2}\right]^{+}$), or a gyroscope (e.g., [ABii + $\left.\mathrm{RNH}_{3}\right]^{+}$, [Mi $\left.+\mathrm{RNH}_{3}\right]^{+}$), in which H-bonding pattern is allowed to rapidly change between the acceptor and

Table 6. Ligand-exchange reactions of ethyl ammonium complexes

\begin{tabular}{|c|c|c|c|c|c|c|c|}
\hline \multirow[b]{2}{*}{ Reagent } & \multirow[b]{2}{*}{ Cavitand } & \multicolumn{2}{|c|}{$\mathrm{EtNH}_{3}{ }^{+}$} & \multicolumn{2}{|c|}{$\mathrm{Et}_{2} \mathrm{NH}_{2}{ }^{+}$} & \multicolumn{2}{|c|}{$\mathrm{Et}_{3} \mathrm{NH}^{+}$} \\
\hline & & $\mathrm{k}_{\exp }{ }^{a}$ & $\mathrm{R}^{2 \mathrm{~b}}$ & $\mathrm{k}_{\exp }{ }^{a}$ & $\mathrm{R}^{2 \mathrm{~b}}$ & $k_{\exp }{ }^{a}$ & $\mathrm{R}^{2 \mathrm{~b}}$ \\
\hline $\mathrm{PrNH}_{2}$ & $\mathrm{Mi}\left[\mathrm{C}_{11} \mathrm{H}_{23}, \mathrm{H}, \mathrm{Ph}\right]$ & 197 & 0.990 & 14.0 & 0.984 & \multicolumn{2}{|c|}{ No exchange } \\
\hline $\mathrm{PrNH}_{2}$ & $\mathrm{ACii}\left[\mathrm{H}, \mathrm{CH}_{3}, \mathrm{Ph}\right]$ & 185 & 0.993 & 9.00 & 0.997 & \multicolumn{2}{|c|}{ No exchange } \\
\hline $\mathrm{PrNH}_{2}$ & $\mathrm{ABii}\left[\mathrm{C}_{11} \mathrm{H}_{23}, \mathrm{H}, \mathrm{Ph}\right]$ & 93.0 & 0.991 & \multicolumn{2}{|c|}{ No exchange } & 1.71 & 0.948 \\
\hline $\mathrm{PrNH}_{2}$ & Tiiii $\left[\mathrm{C}_{11} \mathrm{H}_{23}, \mathrm{H}, \mathrm{Ph}\right]$ & 244 & 0.997 & \multicolumn{2}{|c|}{ No exchange } & \multicolumn{2}{|c|}{ No exchange } \\
\hline $\mathrm{Pr}_{2} \mathrm{NH}$ & $\mathrm{Mi}\left[\mathrm{C}_{11} \mathrm{H}_{23}, \mathrm{H}, \mathrm{Ph}\right]$ & 334 & 0.998 & 29.1 & 0.996 & & \\
\hline $\mathrm{Pr}_{2} \mathrm{NH}$ & $\mathrm{ACii}\left[\mathrm{H}, \mathrm{CH}_{3}, \mathrm{Ph}\right]$ & 86.4 & 0.991 & 1.35 & 0.999 & \multicolumn{2}{|c|}{$\mathrm{n} / \mathrm{d}$} \\
\hline $\mathrm{Pr}_{2} \mathrm{NH}$ & $\mathrm{ABii}\left[\mathrm{C}_{11} \mathrm{H}_{23}, \mathrm{H}, \mathrm{Ph}\right]$ & 312 & 0.995 & \multicolumn{2}{|c|}{ No exchange } & \multirow{4}{*}{\multicolumn{2}{|c|}{$\begin{array}{c}\mathrm{n} / \mathrm{d} \\
\mathrm{n} / \mathrm{d} \\
\text { No exchange } \\
\text { No exchange }\end{array}$}} \\
\hline $\mathrm{Pr}_{2} \mathrm{NH}$ & Tiiii $\left[\mathrm{C}_{11} \mathrm{H}_{23}, \mathrm{H}, \mathrm{Ph}\right]$ & 68.9 & 0.987 & \multicolumn{2}{|c|}{ No exchange } & & \\
\hline i- $\mathrm{PrNH}_{2}$ & $\mathrm{Mi}\left[\mathrm{C}_{11} \mathrm{H}_{23}, \mathrm{H}, \mathrm{Ph}\right]$ & 29.8 & 0.997 & 0.73 & 0.997 & & \\
\hline $\mathrm{i}-\mathrm{PrNH}_{2}$ & $\mathrm{ACii}\left[\mathrm{H}, \mathrm{CH}_{3}, \mathrm{Ph}\right]$ & 110 & 0.996 & 1.93 & 0.998 & & \\
\hline i-PrNH 2 & $\mathrm{ABii}\left[\mathrm{C}_{11} \mathrm{H}_{23}, \mathrm{H}, \mathrm{Ph}\right]$ & 113 & 0.994 & \multicolumn{2}{|c|}{ No exchange } & 3.70 & 0.995 \\
\hline $\mathrm{i}-\mathrm{PrNH}_{2}$ & Tiiii $\left[\mathrm{C}_{11} \mathrm{H}_{23}, \mathrm{H}, \mathrm{Ph}\right]$ & 267 & 0.995 & & & \multicolumn{2}{|c|}{ No exchange } \\
\hline
\end{tabular}

${ }^{a} k_{\text {exp }}=10^{-12} \mathrm{~cm}^{3} \mathrm{~s}^{-1} \mathrm{~mol}^{-1}$.

${ }^{b}$ Correlation of sigmoidal fit. 
(a)

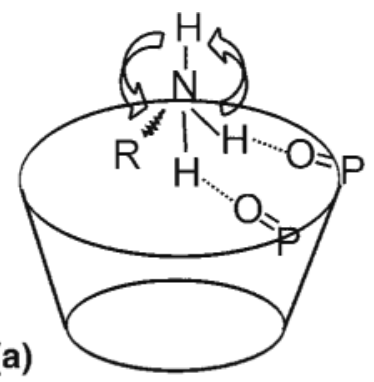

(c)

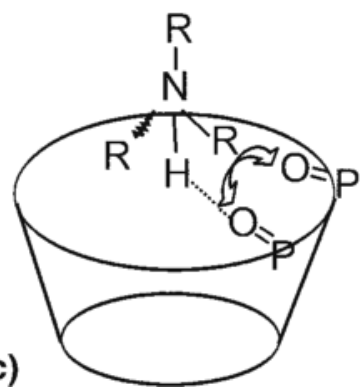

(b)

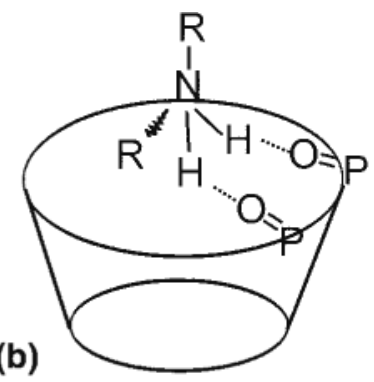

(d)

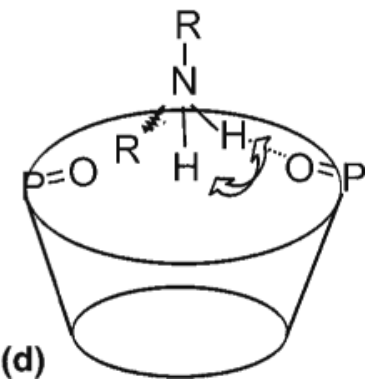

Figure 6. (a) gyroscopic interaction between $\mathrm{ABii}\left[\mathrm{C}_{11} \mathrm{H}_{23}, \mathrm{H}, \mathrm{Ph}\right]$ and $\mathrm{RNH}_{3}^{+}$, (b) stabile interaction between $\mathrm{ABii}\left[\mathrm{C}_{11} \mathrm{H}_{23}, \mathrm{H}, \mathrm{Ph}\right]$ and $\mathrm{R}_{2} \mathrm{NH}_{2}^{+}$, (c) pendulum-interaction between $\mathrm{ABii}\left[\mathrm{C}_{11} \mathrm{H}_{23}, \mathrm{H}\right.$, $\mathrm{Ph}]$, and $\mathrm{R}_{3} \mathrm{NH}^{+}$, and (d) pendulum-interaction between $\mathrm{ACii}[\mathrm{H}$, $\left.\mathrm{CH}_{3}, \mathrm{Ph}\right]$ and $\mathrm{R}_{2} \mathrm{NH}_{2}^{+}$.

donor sites over time (see Figure 6). This enables the gas-phase reactions to take place. Moreover, in the case of a tetraphosphonate cavitand and tertiary ammonium ions, reaction rates were decreased due to the hoop arrangement of the four $\mathrm{P}=\mathrm{O}$ groups, which enables the guest to rapidly change its $\mathrm{H}$-bonding pattern with the host over time, although on average, the cavitand forms only one $\mathrm{H}$-bond. In the ion-molecule reactions of the complexes, the effects arising from steric factors and proton affinity differences complicated the results.

The theoretical calculations generally rationalized the experimental results by showing that the formation of synergistic hydrogen bonds increases the interaction energies. However, occasionally the calculations led to distorted cavitand structures, whose existence in our experimental conditions were not supported by MS results. This difficulty became evident in the case of the ACii cavitand, which was occasionally observed to utilize both its $\mathrm{P}=\mathrm{O}$ groups in complex formation. As the cavitand skeleton rather rigid, it cannot be easily distorted to adapt to complexation. This point must be considered in future optimizations of related cavitand complexes.

\section{Acknowledgments}

The authors gratefully acknowledge financial support from the Finnish Cultural Foundation and the Academy of Finland (project no. 127941).

\section{Appendix A Supplementary Material}

Supplementary material associated with this article may be found in the online version at doi:10.1016/ j.jasms.2009.11.009.

\section{References}

1. Rissanen, K. In Analytical Methods in Supramolecular Chemistry, Schalley, C. A., Ed.; Wiley-VCH: Weinheim, 2007; pp 305-336.

2. (a) Brodbelt, J. S. Probing Molecular Recognition by Mass Spectrometry Int. J. Mass Spectrom. 2000, 200, 57-69. (b) Schalley, C. A. Molecular Recognition and Supramolecular Chemistry in the Gas Phase. Mass Spectrom. Rev. 2001, 20, 253-309. (c) Di Tullio, A.; Reale, S.; De Angelis; F. Molecular Recognition by Mass Spectrometry. J. Mass. Spectrom. 2005, 40, 845-865. (d) Baytekin, B.; Baytekin, T.; Schalley, C. A. Mass Spectrometric Studies of Noncovalent Compounds: Why Supramolecular Chemistry in the Gas Phase? Org. Biomol. Chem. 2006, 4, 2825-2841.

3. (a) Comisarow, M. B.; Mashall, A. G. Fourier Transform Ion Cyclotron Resonance Spectroscopy, Chem. Phys. Lett. 1974, 25, 282-283. (b) Amster, I. J. Fourier Transform Mass Spectrometry, J. Mass. Spectrom. 1996, 31, 1325-1337.

4. (a) Brodbelt, J. S. Analytical Applications of Ion-Molecule Reactions. Mass Spec. Rev. 1997, 16, 91-110. (b) Green, M. K.; Lebrilla, C. B. Ion-molecule Reactions as Probes of Gas-Phase Structures of Peptides and Proteins. Mass. Spec. Rev. 1997, 16, 53-71.

5. Kellersberger, K. A.; Dejsupa, C.; Liang, Y.; Pope, R. M.; Dearden, D. V. Gas Phase Studies of Ammonium-Cyclodextrin Compounds using Fourier Transform Ion Cyclotron Resonance. Int. J. Mass Spectrom. 1999, 193, 181-195.

6. Nuutinen, J. M. J.; Irico, A.; Vincenti, M.; Dalcanale, E.; Pakarienn, J. M. H.; Vainiotalo, P. Gas-Phase Ion-Molecule Reactions Between a Series of Protonated Diastereomeric Cavitands and Neutral Amines Studied by ESI-FTICRMS: Gas-Phase Inclusion Complex Formation, J. Am. Chem. Soc. 2000, 122, 10090-10100.

7. (a) Speranza, M. Enantioselectivity in Gas-Phase Ion-Molecule Reactions. Int. J. Mass Spectrom. 2004, 232, 277-317. (b) Dearden D. V. Dejsupa, C.; Liang, Y.; Bradshaw, J. S.; Izatt, R. M. Intrinsic Contributions to Chiral Recognition: Discrimination Between Enantiomeric Amines by Dimethylketopyridino-18-Crown-6 in the Gas Phase. J. Am. Chem. Soc. 1997, 119, 353-359. (c) Grigorean, G.; Cong, X.; Lebrilla, C. B. Chiral Analyses of Peptides by Ion/Molecule Reactions. Int. J. Mass Spectrom. 2004, 234, 71-77. (d) Hyyryläinen, A. R. M.; Pakarinen, J. M. H.; Forró, E.; Füllop, F.; Vainiotalo, P. J. Am. Chem. Soc. Mass Spectrom. 2009, 20, 1235-1241.

8. (a) Ventola, E.; Rissanen, K.; Vainiotalo, P. Mass Spectrometric Investigation of Noncovalent Complexation between a Tetratosylated Resorcarene and Alkyl Ammonium Ions. Chem. Eur. J. 2004, 10, 6152-6162. (b) Ventola, E.; Hyyryläinen, A.; Vainiotalo, P. Complex Formation Between a Tetramesityl Sulfonated Resorcarene and Alkylammonium Ions: A Mass Spectrometric Study of Noncovalent Interactions. Rapid Commun. Mass Spectrom. 2006, 20, 1218-1224.

9. (a) Dutasta, J.-P. New Phosphorylated Hosts for the Design of New Supramolecular Assemblies. Top. Curr. Chem. 2004, 232, 55-91. (b) Pinalli, R.; Suman, M.; Dalcanale, E. Cavitands at Work: From Molecular Recognition to Supramolecular Sensors. Eur. J. Org. Chem. 2004, 451-462. (c) Lippmann, T.; Dalcanale, E.; Mann, G. Synthesis and Configurational Analysis of Phosphorus Bridged Cavitands, Tetrahedron. Lett. 1994, 35, 1685-1688. (d) Jacopozzi, P.; Dalcanale, E.; Spera, S. Chrisstoffels, L. A. J.; Reinhoudt, D. N.; Lippmann, T.; Mann, G. Synthesis and Configurational Analysis of Phosphonate Cavitands. J. Chem. Soc., Perkin Trans. 1998, 2, 671-677.

10. Pirondini, L.; Dalcanale, E. Molecular Recognition at the Gas-Solid Interface: A Powerful Tool for Chemical Sensing. Chem. Soc. Rev. 2007, 36, 695-706.

11. Pinalli, R.; Nachtigall, F. F.; Ugozzoli, F.; Dalcanale, E. Supramolecular Sensors for the Detection of Alcohols. Angew. Chem. Int. Ed. Engl. 1999, 38, 2377-2380.

12. Suman, M.; Freddi, M.; Massera, C.; Ugozzoli, F.; Dalcanale, E. Rational Design of Cavitand Receptors for Mass Sensors. J. Am. Chem. Soc. 2003, $125,12068-12069$.

13. Melegari, M.; Suman, M.; Pirondini, L.; Moiani, D.; Massera, C.; Ugozolli, F.; Kalenius, E.; Vainiotalo, P.; Mulatier, J.-C.; Dutasta, J.-P.; Dalcanale, E. Supramolecular Sensing with Phosphonate Cavitands. Chem. Eur. J. 2008, 14, 5772-5779.

14. Ventola, E.; Vainiotalo, P.; Suman, M.; Dalcanale, E. ESI-FTICR Mass Spectrometric Complexation of Mono- and Diphosphonate Bridged Cavitands. I. Am. Soc. Mass Spectrom. 2006, 17, 213-221.

15. Irico, A.; Vincenti, M.; Dalcanale, E. Diastereoselective Formation of Host-Guest Complexes Between a Series of Phosphate-Bridged Cavitands and Alkyl- and Arylammonium Ions Studied by Liquid SecondaryIon Mass Spectrometry.Chem. Eur. J. 2001, 7, 2034-2042. 
16. Kalenius, E.; Moiani, D.; Dalcanale, E.; Vainiotalo, P. Measuring HBonding in Supramolecular Complexes by Gas Phase Ion-Molecule Reactions. Chem. Commun. 2007, 3865-3867.

17. Yebeutchou, R. M.; Tancini, F.; Demitri, N.; Geremia, S.; Mendichi, R.; Dalcanale, E. Host-Guest Driven Self-Assembly of Linear and Star Supramolecular Polymers. Angew. Chem. Int. Ed. 2008, 47, 4504-4508.

18. Biavardi, E.; Favazza, M.; Motta, A.; Fragala, I. L.; Massera, C.; Prodi, L.; Montalti, M.; Melegari, M.; Condorelli, G. G.; Dalcanale, E. Molecular Recognition on a Cavitand-Functionalized Silicon Surface, J. Am. Chem. Soc. 2009, 131, 7447-7455.

19. Yebeutchou, R. M.; Dalcanale, E. Highly Selective Monomethylation of Primary Amines Through Host-Guest Product Sequestration. J. Am. Chem. Soc. 2009, 131, 2452-2453.

20. Delangle, P.; Mulatier, J.-C.; Tinant, B.; Declercq, J.-P.; Dutasta, J.-P. Synthesis and Binding Properties of iiii (4i) Stereoisomers of Phosphonato Cavitands-Cooperative Effects in Cation Complexation in Organic Solvents Eur. J. Org. Chem. 2001, 3695-3704.

21. Woodget, B. W.; Cooper, D. Samples and Standards; Wiley: Chichester, 1987; p. 40-47.

22. Hamilton, L. F.; Simpson, S. G.; Ellis, D. W. Calculations of Analytical Chemistry; McGraw-Hill: New York, 1960; p. 2-11.

23. McGormick, D.; Roach, A. Measurements, Statistics, and Computation; Wiley: Chichester, 1987; p. 24-31.

24. de Koning, L. J.; Nibbering, N. M. M.; van Orden, S. L.; Laukien, F. H. Mass Selection of Ions in a Fourier Transform Ion Cyclotron Resonance
Trap Using Correlated Harmonic Excitation Fields (CHEF). Int. J. Mass Spectrom. Ion Processes 1997, 165/166, 209-219.

25. Hop, C. E. C. A.; McMahon, T. B.; Willett, G. D. Determination of Bond Dissociation Energies via Energy-Resolved Collision Induced Dissociation in a Fourier Transform Ion Cyclotron Resonance Spectrometer. Int J. Mass Spectrom. Ion Processes 1990, 101, 191-208

26. Sievers, H. L.; Grützmacher, H.-F.; Caravatti, P. The Geometrical Factor of Infinitely Long Cylindrical ICR Cells for Collision Energy-Resolved Mass Spectrometry: Appearance Energies of $\mathrm{EI}_{2}^{+}(\mathrm{E}=\mathrm{P}, \mathrm{As}, \mathrm{Sb}$, and $\mathrm{Bi})$ from Collision-Induced Dissociation of $\mathrm{EI}_{3}^{+}$and $\left[\mathrm{EI}_{2} \bullet \text { ligand }\right]^{+} \mathrm{Com}-$ plexes. Int. J. Mass Spectrom. Ion Processes 1996, 157/158, 233-247.

27. Heeren, R. M. A.; Vékey, K. A Novel Method to Determine Collisional Energy Transfer Efficiency by Fourier Transform Ion Cyclotron Resonance Mass Spectrometry. Rapid Commun. Mass Spectrom. 1998, 12, 1175-1181.

28. He, F.; Marshall, A. G. J. Phys. Chem. A 2005, 109, 2107-2112.

29. Ahlrichs, R.; Bär, M. Häser, M.; Horn, H.; Kölmel, C. Electronic Structure Calculations on Workstation Computers: The Program System Turbomole. Chem. Phys. Lett. 1989, 162, 165-169.

30. Cooks, R. G.; Patrick, J. S.; Kotiaho, T.; McLuckey, S. A. Thermochemical Determinations by the Kinetic Method. Mass Spectrom. Rev. 1994, 13, 287-339.

31. Biavardi, E.; Battistini, G.; Montalti, M.; Yebeutchou, R. M.; Prodi, L.; Dalcanale, E. Fully Reversible Guest Exchange in Tetraphosphonate Cavitand Complexes Probed by Fluorescence Spectroscopy, Chem. Commun. 2008, 1638-1640. 